\title{
MEDEDEELINGEN VAN HET INSTITUUT VOOR PHYTOPATHOLOGIE EN \\ VAN DEN PHYTOPATHOLOGISCHEN DIENST.
}

Tot dusver verschenen van het Instituut voor Phytopatho= logie de volgende vlugschriften, verkrijgbaar op aanvrage bij den Directeur van het Instituut voor phytopathologie te Wageningen tegen toezending van 2 cts. per exemplaar.

No. 1. April 1917 Bladluizen. (3de druk).

No. 2. April $191+$ Schildluizen. (2de druk).

No. 3. Juli " Bladaaltjes. (2de druk).

No. 4. Nov. " Resultaten van proeven met Californische pap. (3de druk).

No. 5. Mei "Sproeimachines. (2de druk).

No. . Juli " Bereiding van Bordeauxsche pap. Normaal pappoeder. Het mengen van arsenicum-prae-

N 7. Juni paraten onder Bordeauxsche pap. (22de druk). Bereiding van Californische pap (en Scott'sche pap). Het mengen van arsenicumpraeparaten onder Calif. pap. (2de druk).

No. 8. Juli " Bereiding van carbolineum voor besproeiing. Zeep-spiritusoplossing. Schweinfurter of

No. 9. Nov. 1917 Selderieziekten. (4de druk).

$\mathrm{N}^{\circ}$. 10. Jan. 1916 Koolziekten. (2de druk).

No. 11. Juni 1914 Eenige Rhododendron-vijanden.

$\mathrm{N}^{0}$. 12. Juni $191+$ Eenige belangrijke rozenvijanden.

No. 13. Aug. 1916 De kankerziekte der ooftboomen. (2de druk).

No. 14. Juni 1914 De kleine wintervlinder.

$\mathrm{N}^{\circ}$. 15. April 1915 De fritvlieg.

No. 16. Febr. 1917 De behandeling van zaaitarwe tegen schimmels, die de kiem aantasten.

No. 17. Mei 1917 De bessenbladwesp.

Deze vlugschriften behandelen het onderwerp, in den titel van elk vlugschrift aangeduid, geheel met het oog op de praktijk, en wel in algemeen verstainbaren en zoo beknopt mogelijken vorm.

Ook verschenen de volgende mededeelingen van den Phyto= pathologischen Dienst, verkrijgbaar tegen de bijgevoegde prijzen, op aanvrage bij het Hoofd zan den phytopathologischen dienst te Wageningen.

No. 1. De spruitvreter of knopworm der bessenstruiken

$N^{9}$. 2. De roode worm der frambozen

No. 3. De trekmade

Ne. 4. Steen-en stuifbrand v. tarwe en gerst

f 0.10 , fr. p. p. $\mathrm{f} 0.12$.

f 0.10 , fr. p. p. f 0.12 .

No. 5. Dopluis op perzik en druif

f0.1א, fr. p. p. t 0.20 .

fr. p. p. 10.25 .

f 0.15 , fr. p. p. f 0.17 .

De Directeur van het Instituut voor

Phytopathologie, Hoofd van den Phytopathologischen dienst:

J. RITZEMA BOS. 